\title{
CONSILIUM
}

Berkala Kajian Konseling Dan Ilmu Keagamaan

Avalaible at http://jurnal.uinsu.ac.id/index.php/consilium

ISSN : 2338-0608 (Print) | ISSN : 2654-878X (Online)

\section{Kontribusi Layanan Penguasaan Konten dalam Meningkatkan Sikap Empati Siswa}

\author{
Evi Fitriyanti*, Solihatun, Tanti Ardianti. \\ Universitas Indraprasta PGRI Jakarta, DKI. Jakarta, Indonesia \\ *Korespondensi: evifitriyanti_21@yahoo.com
}

\begin{abstract}
This study aims to reveal how much the contribution of Content Satisfaction Services (PKO) in increasing students' empathy attitudes at SMK Taruna Bhakti Depok. This research uses a quantitative method with a descriptive correlational analysis approach that aims to find out how much influence between the research variables. This research variable consists of two, namely Content Mastery Service (PKO) (X) is an independent variable and Student Empathy Attitude $(Y)$ is a dependent variable. Through PKO services provided to students in a classical format it is expected to help students have something useful to meet their needs and overcome the problems they face, especially in increasing students' empathy. The results showed that there was a contribution to the content mastery service (PKO) in significantly increasing students' empathy attitudes.
\end{abstract}

Keywords: Content Mastery Service, Empathy attitude, Student

\section{PENDAHULUAN}

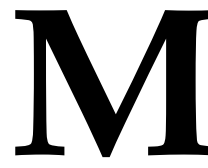

anusia merupkan makhluk sosial yang membutuhkan orang lain dalam kehidupannya, dalam kehidupan sosial tersebut terdapat hubungan dimana individu mampu untuk dapat merasakan apa yang dirasakan oleh orang lain, dimana hal tersebut dikatakan sebagai kondisi manusia yang dapat berempati. Namun kondisi kehidupan sosial sekarang ini banyak memperlihatkan kurangnya sikap empati, seperti diungkapkan oleh Catur waskito Edy (2018) Salah satu media asing, The Guardian melalui Jamie, menyeroti aktifitas warga yang justru menjadikan kondisi pasca-tsunami selat sunda di Banten untuk berswafoto atau selfie. Kepada Jamie, mereka mengaku berselfie untuk eksistensi serta mendapatkan banyak like di media-media sosial. Pemberitaan tersebut menjadi sorotan karena warga masyarakat yang berselfie dinilai kurang berempati terhadap korban bencana. Kondisi yang demikian dapat dijadikan sebagai contoh perilaku tidak baik terutama oleh para siswa yang mampu mengakses pemberitaan melalui peggunaan internet melalui 
teknologi yang berkembang. Lebih dalam pada diri siswa akan dapat mengikis sikap empati yang dimiliki terhadap sesama, siswa sebagai peserta didik memegang kunci untuk keberlangsungan masa depan bangsa dan negara, namun dalam keyataannya banyak dijumpai sikap acuh terhadap masyarakat dan lingkungan sekitarnya, oleh sebeb itu sikap empati perlu untuk dilatih dan dikembangkan agar keberadaannya dalam diri siswa dapat berfungsi dengan optimal, seperti diungkapkan oleh Dewi, dkk (2014) menjelaskan bahwa sikap empati sudah tumbuh dari sejak lahir, harus dipupuk dan dikembangkan karena sikap empati sangat diperlukan dalam kehidupan sehingga sikap empati dapat dimiliki oleh siswa.

Empati merupakan arti dari kata einfulung yang dipakai oleh para psikolog Jerman. Secara harfiah ia berarti merasakan ke dalam. Empati berasal dari kata Yunani phatos, yang berarti perasaan yang mendalam dan kuat yang mendekati penderitaan, maka empati mengacu pada keadaan identifikasi kepribadian yang lebih mendalam kepada seseorang, sehingga seseorang yang berempati sesaat melupakan atau kehilangan dirinya sendiri (Emi Indriasari, 2016). Byrne \& Baron (dalam Alan Auliyah dan Elia Flurentin, 2016), menyatakan bahwa empati merupakan kemampuan individu untuk dapat merasakan perasaan atau pengalaman orang lain. Oleh karena itu, dengan mempunyai sikap empati seorang individu dapat berbagi perasaan dengan orang lain dalam suasana suka maupun duka, kesediaan memberikan bantuan kepada orang lain baik materiil maupun moril dan juga kesediaan untuk bekerjasama dengan orang lain demi tercapainya suatu tujuan. Berdasarkan apa yang telah duraikan sebelumnya maka empati dimaksudkan dengan kemampuan memahami masalah dan perasaan orang lain dengan berfikir melalui sudut pandang mereka, menghargai perbedaan, menumbuhkan hubungan saling percaya, dan menyelaraskan diri dengan karakteristik berbagai macam pribadi. Kemampuan empati akan mendorong individu mampu melihat permasalahan dengan lebih jernih dan menempatkan objektivitas dalam memecahkan masalah. Banyak alternatif yang memungkinkan dapat diambil manakala individu dapat berempati dengan orang lain dalam menghadapi masalah. Tanpa adanya empati dirasakan akan sulit bagi individu untuk megetahui apa yang sedang dihadapi seseorang karena ketidakmampuan individu untuk dapat memasuki perasaan dan memahami kondisi yang sedang dialami oleh orang lain. 
Sikap empati bisa diartikan sebagai sebuah kemampuan untuk memahami situasi dan perasaan yang dialami orang lain kemudian meresponnya dengan perilaku positif, namun belakangan banyak siswa yang tidak dapat menempatkan sikap empati dengan tidak semestinya dikarenakan berbagai macam faktor. Seperti diungkapkan oleh School Of Parenting (2018) menerangkan bahwa ada sejumlah teori yang berkaitan dengan kurangnya kebaikan hati dan sikap tolong menolong di antara generasi ini, dan bagaimana mereka menjadi kurang berempati dari pada generasi sebelumnya, dimana generasi sekarang ini mengembangkan sifat narsistik yang berlebihan serta kurang dalam keterampilan sosial dan emosional. Dalam lingkungan sosial yang terdapat banyak perubahan seperti sekarang ini, keterampilan tentang sikap empati dan kebaikan sangat perlu diajarkan terus-menerus di lingkungan pendidikan karena melalui sikap empati akan membantu siswa sebagai bagian dari masyarakat untuk dapat membangun hubungan yang rasional dan autentik di dalam mengisi pembangunan, selain itu juga memiliki sikap empati sangatlah penting sebagai pondasi dari rasa saling menghargai dan menghormati satu sama lain di dalam bermasyarakat. Seperti diungkapkan oleh Tarigan (2016) bahwa empati merupakan dasar dari semua sikap sosial, sehingga memiliki peranan yang sangat besar bagi siswa sebagai seorang remaja baik dalam kehidupan pribadi maupun kelompok sosialnya.

Empati sebagai kemampuan untuk dapat merasakan perasaan orang lain mempunyai ciri-ciri tertentu yang diimplementasikan dalam bentuk perilaku. (Borba dalam Putri Meidina, 2018), menjelaskan bahwa ciri-ciri perilaku empati terbagi menjadi:

1. Toleransi

Menghargai, pendirian pendapat, pandangan, kepercayaan, kebiasaan, kelakuan dan sebagainya yang lain atau yang bertentangan dengan pendirinya sendiri.

2. Kasih sayang

Kasih sayang didefinisikan bahwa kasih itu tidak menyakiti, tidak bersuka cita karena ketidakadilan tetapi karena kebenaran.

3. Memahami kebutuhan orang lain

Memenuhi kebutuhan orang lain dapat mengatasi suatu masalah yang dihadapi orang lain.

4. Mau membantu orang lain (menolong)

Perilaku menolong adalah perilaku yang menguntungkan orang lain.

5. Pengertian 
Anak yang penuh pengertian akan menghibur temannya yang sedang sedih, mendengarkan saat guru atau teman sedang berbicara, mendoakan agar teman cepat sembuh, dan lain-lain.

6. Peduli

Sikap anak yang memiliki kepedulian adalah menghampiri teman yang sedang kesusahan, menghibur teman yang sedang sedih, serta membantu teman yang membutuhkan pertolongan.

7. Mampu mengendalikan amarahnya

Mengendalikan emosi, dapat dilihat dari sikap anak yang mampu mengekspresikan emosinya secara tepat

Berdasarkan pendapat para ahli diatas dapat dilihat bahwa individu yang memiliki sikap empati ditunjukan dengan ciri-ciri mampu berkomunikasi dengan orang lain dengan memahami apa yang dikomunikasikannya terkait dengan kondisi perasaaan yang sedang dirasakan oleh orang lain, peka terhadap apa yang dialami oleh orang lain, mampu menjadi pendengan yang baik terhadap apa yang sedang dirasakan orang lain, memliki sikap perduli dan mampu mengendalikan emosi.

Sekolah merupakan wadah dalam pencapaian tujuan pendidikan dimana siswa sebagai peserta didik diharapkan kelak mampu menjadi sumberdaya yang mumpuni dalam memajukan bangsa, dengan tetap memunculkan sikapsikap yang positif dimana salah satunya adalah sikap empati. Seperti diungkapkan oleh Ahmad Baedowi (2017), menjelaskan bahwa sekolah harus menjadi titik tumpu permulaan dalam melatihkan empati dan kebaikan kepada anak-anak kita sebagai siswa. Sebagai sebuah keterampilan, empati dan kebaikan merupakan perkara besar dan mendasar yang harus menjadi acuan proses belajar-mengajar di dalam ruang-ruang kelas. Dengan menanamkan empati dan kebaikan ke dalam pemikiran para siswa, maka ketika dimanfaatkan, sikap empati tersebut akan memainkan peran penting dalam melakukan inovasi, perubahan keputusan, dan memecahkan masalah secara sistematis. Melalui pendidikan di sekolah, diharapkan dapat menciptakan suasana pembelajaran yang mampu mengembangkan sikap empati siswa melalui bantuan proses pembelajaran yang dilaksanakan oleh para pendidik pada tiap tingkat satuan pendidikan. Suasana dan proses pembelajaran yang dimaksudkan tersebut dapat dilakukan melalui kegiatan bimbingan konseling di sekolah, dimana bimbingan konseling merupakan kegiatan yang pelaksanaannya tidak dapat lepas dari setting pendidikan, secara umum 
pelaksanaan bimbingan konseling melalui penerapan layanannya bertujuan membantu individu untuk dapat mengenal dan menerima dirinya, mengenal dan menerima lingkungannya secara positif, serta mampu mengambil keputusan sesuai dengan keadaan dirinya. Senada dengan yang diungkapkan oleh Kamaludin (2011) yang menyatakan bahwa dasar pemikiran penyelenggaraan bimbingan dan konseling di sekolah bukan semata-mata terletak pada ada atau tidak adanya landasan hukum (perundang-undangan) atau ketentuan dari atas, namun yang lebih penting adalah menyangkut upaya memfasilitasi peserta didik yang selanjutnya disebut konseli, agar mampu mengembangkan petensi dirinya atau mencapai tugas-tugas perkembangannya (menyangkut aspek fisik, emosi, intelektual, sosial dan moral-spiritual).

Salah satu layanan yang digunakan dalam kegiatan bimbingan konseling disekolah adalah layanan penguasaan konten yang disingkat menjadi (PKO). Layanan penguasaan konten merupakan layanan bantuan kepada individu (sendiri-sendiri ataupun dalam kelompok) untuk menguasai kemampuan atau kompetensi tertentu melalui kegiatan belajar. Kemampuan atau kompetensi yang dipelajari itu merupakan satu unit konten yang di dalamnya terkandung fakta dan data, konsep, proses, hukum, dan aturan, nilai, persepsi, afeksi, sikap dan tindakan yang terkait di dalamnya. Layanan penguasaan konten membantu individu menguasai aspek-aspek konten tersebut secara tersinergikan. Dengan penguasaan konten, individu diharapkan mampu memiliki sesuatu yang berguna untuk memenuhi kebutuhannya serta mengatasi masalah-masalah yang dialaminya (Prayitno dalam Numri, 2015). Di sekolah guru BK mempunyai tugas dan tanggung jawab membantu siswa dalam meningkatkan hasil belajar yang optimal dengan mendorong siswa dengan kebiasaan-kebiasaan yang baik dalam kegiatan belajar (Hezy, Firman \& Ifdil, 2014). Isi dari layanan penguasaan konten adalah sebuah konten yang merupakan materi latihan yang dikembangkan oleh konselor meliputi bidang-bidang sebagai berikut (Prayitno dalam Farida, 2014): a) pengembangan kehidupan pribadi b) pengembangan kemampuan hubungan sosial c) pengembangan kegiatan belajar d) pengembangan dan perencanaan karir e) pengembangan kehidupan keluarga f) pengembangan kehidupan beragama.

Menurut Azam (2016), menjelaskan bahwa di dalam penjelasan tentang hakikat layanan penguasaan konten, secara implisit telah ditegaskan tujuan layanan penguasaan konten yaitu agar siswa menguasai aspek-aspek konten (kemampuan atau kompetensi) tertentu secara terintegrasi. Kemudian, menurut 
Tohirin (2014) mengatakan bahwa tujuan layanan penguasaan konten yaitu agar peserta didik menguasai aspek-aspek konten tertentu secara terintegrasi (kesatuan yang utuh). Dengan penguasaan konten oleh peserta didik, akan berguna untuk menambah wawasan dan pemahaman, mengarahkan penilaian sikap, menguasai cara-cara tertentu, dalam rangka memenuhi kebutuhan dan mengatasi masalah-masalahnya. Berdasarkan uraian di atas, maka dapat diungkapkan bahwa tujuan dari layanan penguasaan konten adalah agar setiap siswa dapat menguasai aspek-aspek konten tertentu secara terintegrasi dan dapat menambah wawasan, pengetahuan, pemahaman, nilai dan sikap, untuk mampu mengatasi masalah yang sedang dihadapinya berdasarkan kebutuhannya.

SMK Taruna Bhakti Depok merupakan sekolah yang mengedepankan nilai-nilai life skill terhadap peserta didiknya terutama yang berkaitan juga dengan pengembangan dan peningkatan sikap empati, untuk itu melalui observasi yang peneliti lakukan di sekolah tersebut terlihat bahwa guru BK sangat berupaya melaksanakan layanan konseling sesuai kebutuhan dan program yang telah dibuat, namun dalam perjalannya guru BK memiliki keterbatasan dalam melaksanakan setiap layanan dalam bimbingan konseling, yang lebih sering melaksanakan layanan konseling individual dan layanan informasi dibandingkan dengan penggunaan layanan lainnya, berdasarkan hal tersebut peneliti berdiskusi mengenai kebutuhan siswa yang dirasa paling mendesak dengan mengkolaborasikan pelaksanaan layanan penguasaan konten (PKO) oleh guru BK kepada siswa. Atas dasar latar belakang tersebut maka tim peneliti memutuskan untuk melaksanakan penelitian dengan judul "Kontribusi Layanan Penguasan Konten (PKO) dalam Meningkatkan Sikap Empati Siswa di SMK Taruna Bhakti Depok".

\section{METODE PENELITIAN}

Penelitian ini menggunakan metode kuantitatif dengan pendekatan analisis deskriptif korelasional yang bertujuan untuk mengetahui seberapa besar pengaruh antar variabel penelitian. Variabel penelitian ini terdiri dari dua, yaitu: Layanan Penguasaan Konten (PKO) merupakan variabel bebas $(X)$ dan Sikap Empati Siswa merupakan variabel terikat (Y). Populasi dalam penelitian ini, yaitu terdiri dari siswa/siswa di SMA Taruna Bakti yang berjumlah 1536 dengan rincian sebagai berikut : 
Tabel 1. Populasi Penelitian

\begin{tabular}{|c|c|c|c|}
\hline Kelas & Detail & Jumlah & Total \\
\hline \multirow[t]{2}{*}{10} & $\mathrm{~L}$ & 386 & \multirow[t]{2}{*}{618} \\
\hline & $\mathrm{P}$ & 232 & \\
\hline \multirow[t]{2}{*}{11} & $\mathrm{~L}$ & 344 & \multirow[t]{2}{*}{578} \\
\hline & $\mathrm{P}$ & 234 & \\
\hline \multirow[t]{2}{*}{12} & $\mathrm{~L}$ & 185 & \multirow[t]{2}{*}{340} \\
\hline & $\mathrm{P}$ & 155 & \\
\hline
\end{tabular}

Arikunto mengemukakan untuk sekedar asumsi maka apabila subyeknya kurang dari seratus lebih baik diambil semua, sehingga penelitiannya merupakan penelitian populasi, Jika jumlah subyeknya besar perlu dipertimbangkan kemampuan, waktu, tenaga, sempit luasnya wilayah pengamatan dan resiko yang ditanggung peneliti, namun sebagai asumsi dapat diambil $10 \%$ sampai dengan $15 \%$ atau $20 \%$ sampai dengan $25 \%$ atau lebih (Arikunto, 2002).Maka ditetapkan jumlah sampel pada penelitian ini adalah sebanyak $10 \%$ atau 154 siswa. Data dalam penelitian ini dikumpulkan dengan menggunakan angket melalui teknik skala. Skala yang dimaksud adalah skala mengenai sikap empati siswa. Skala yang dibuat adalah skala Likert dengan lima alternatif jawaban, yakni SS (Sangat Sesuai), S (Sesuai), RR (Ragu-ragu), TS (Tidak Sesuai), dan STS (Sangat Tidak Sesuai). Data penelitian dianalisis dengan menggunakan teknik korelasi dan regresi. Analisis data dilakukan dengan bantuan komputer program SPSS versi 20 dengan langkah analisis sebagai berikut:

1. Analisis Deskriptif

Analisis deskriptif dilakukan dengan tujuan melihat kecendrungan distribusi frekuensi variabel dan menentukan tingkat ketercapaian responden pada masing-masing variabel. Tingkat pencapaian responden pada masing-masing variabel akan diketahui melalui rumus (Sudjana, 1996:50):

Sedangkan pengkategorian nilai pencapaian responden digunakan klasifikasi sebagai berikut: 
Tabel 2. Kategorisasi Deskriptif

\begin{tabular}{cc}
\hline Prosentase & Kategori \\
\hline $90-100 \%$ & Sangat Baik \\
\hline $80-89 \%$ & Baik \\
\hline $65-79 \%$ & Cukup \\
\hline $55-64 \%$ & Kurang Baik \\
\hline $0-54 \%$ & Tidak Baik \\
\hline
\end{tabular}

2. Pemeriksaan Persyaratan Analisis

a. Uji normalitas

Uji normalitas bertujuan untuk melihat sebaran data ketiga variabel penelitian, apakah data berasal dari populasi yang berdistribusi normal atau tidak. Pengujian normalitas diperlukan untuk menetapkan pemakaian teknik analisis yang cocok digunakan pada penelitian ini.

b. Uji homogenitas

Uji homogenitas bertujuan untuk memeriksa homogenitas varian kelompok sampel penelitian.

c. Pemeriksaan kemandirian variabel

Tujuan pemeriksaan kemandirian variabel adalah untuk memeriksa independensi variabel bebas.

d. Uji linearitas

Uji linearitas bertujuan untuk mengetahui apakah terdapat hubungan linear antara variabel bebas dengan variabel terikat..

3. Pengujian Hipotesis

Hipotesis dianalisis dengan teknik korelasi dan regresi sederhana

\section{HASIL PENELITIAN DAN PEMBAHASAN}

Berdasarkan hasil penelitian ini akan disajikan mengenai analisis dan pembahasan hasil pengolahan data penelitian yang meliputi deskripsi data, pengujian persyaratan analisis, pengujian hipotesis penelitian, dan interpretasi serta pembahasan hasil penelitian. Dalam menganalisis data diarahkan pada pengujian hipotesis, yang diawali dengan deskripsi data penelitian dari ketiga variabel dalam bentuk distribusi frekuensi, ukuran gejala pusat dan histogramnya serta menentukan persamaan regresinya. Untuk menggambarkan pengaruh satu-satu antar variabel dilakukan dengan analisis regresi sederhana.Penulis menyajikan data penelitian untuk variabel sikap empati siswa $(Y)$, dan layanan penguasaan konten dengan teknik modelling simbolik $(\mathrm{X})$. Adapun hasilnya adalah sebagai berikut: 
Tabel 3. Deskripsi Statistik Variabel sikap empati siswa dan Layanan Penguasaan Konten

\begin{tabular}{|c|c|c|}
\hline & $\begin{array}{l}\text { Sikap Empati } \\
\text { Siswa }\end{array}$ & $\begin{array}{c}\text { Iayanan } \\
\text { penguasaan } \\
\text { konten } \\
\text { dengan } \\
\text { modelling } \\
\text { simbolik }\end{array}$ \\
\hline Valid & 154 & 154 \\
\hline Missing & & 0 \\
\hline Mean & 131.16 & 79.13 \\
\hline Median & 133.00 & 79.00 \\
\hline Made & 150 & 80 \\
\hline Std. Deviation & 14.962 & 8.116 \\
\hline Skewness & -.633 & -.016 \\
\hline Std. Error of Skewness & .195 & .195 \\
\hline Kurtosis & -.408 & -.054 \\
\hline Std. Error of Kurtosis & .389 & .389 \\
\hline Range & 57 & 38 \\
\hline Minimum & 93 & 60 \\
\hline Maximum & 150 & 98 \\
\hline
\end{tabular}

Berdasarkan data sikap empati siswa diperoleh dari hasil angket sebanyak 154 siswa yang menjadi sampel penelitian terlihat skor terendah 93, tertinggi 150, rata-rata sebesar 131,16, median sebesar 133,00, modus sebesar 150 dan simpangan baku sebesar 14,962. Untuk memperjelas data di atas, digambarkan dalam histogram sebagai berikut:

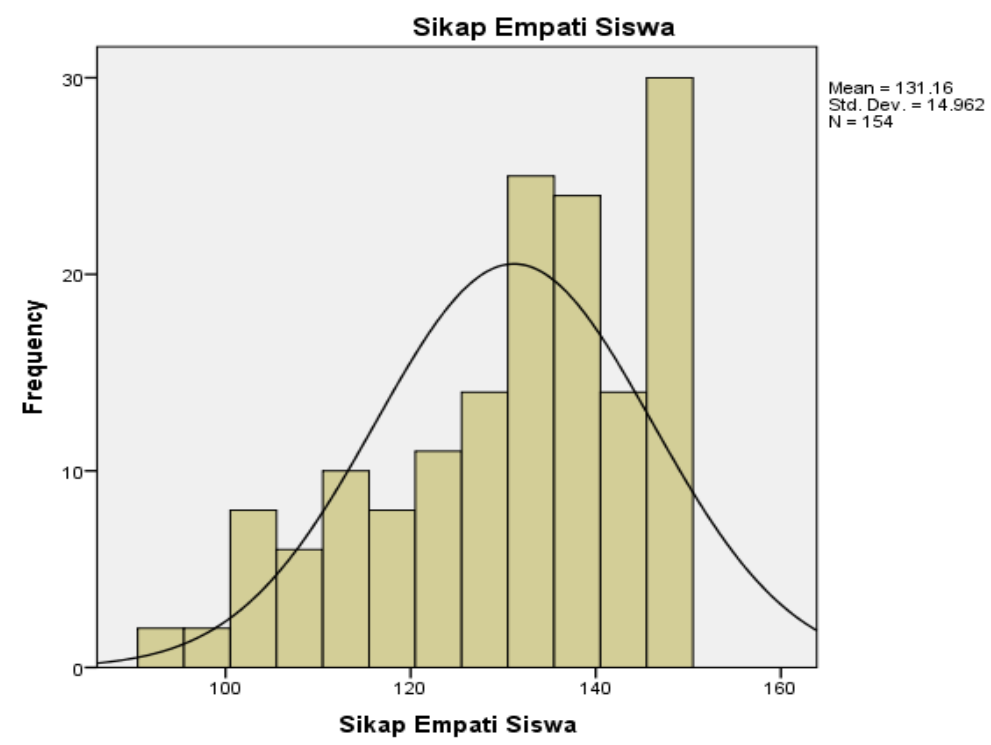

\section{Gambar 1. Histogram Poligon Data Penelitian Sikap Empati Siswa}

Berdasarkan tabel 3 juga terlihat data layanan penguasaan konten dengan modelling simbolik yang diperoleh dari hasil angket sebanyak 154 siswa yang menjadi sampel penelitian terlihat skor terendah 60, tertinggi98, rata-rata sebesar 79,13, median sebesar 79,00, modus sebesar 80 dan simpangan baku 
sebesar 8,116. Untuk memperjelas data di atas, digambarkan dalam histogram sebagai berikut:

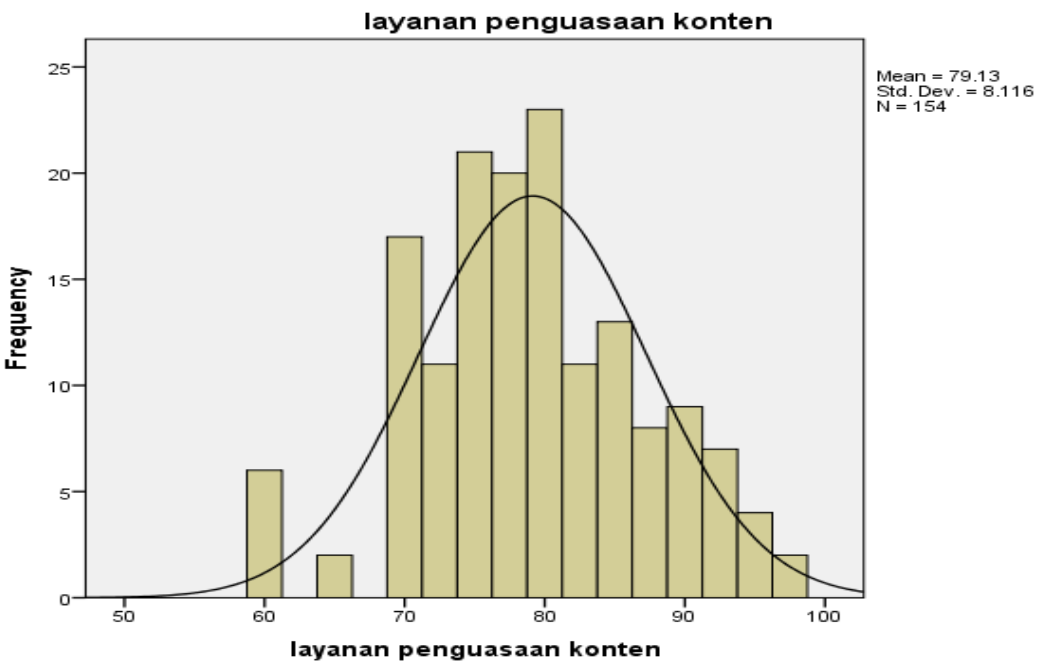

\section{Gambar 2. Histogram Poligon Data Penelitian Kotribusi layanan Penguasaan Konten}

Berdasarkan hasil perhitungan di atas, maka dapat dikatakan bahwa sikap empati siswa dan layanan penguasaan konten dengan teknik modelling simbolik tergolong baik. Hal tersebut terindikasi dari perolehan masing- masing nilai rata- ratanya. Dari histogram dan polygon frekuensi di atas dapat disimpulkan bahwa sikap empati siswa dan layanan penguasaan konten dengan teknik modelling simbolik SMA Taruna Bhakti memiliki sebaran yang normal. Sebelum dilakukan pengujian hipotesis, data yang diterima kemudian dilakukan pengujian persyaratan analisis data yang dilakukan dalam penelitian ini adalah pengujian normalitas dan linearitas. Berikut pengujian persyaratan analisis data tersebut. 


\section{Tabel 4. Hasil Uji Normalitas Data}

One-Sample Kolmogorov-Smirnov Test

\begin{tabular}{|ll|r|r|}
\hline & & $\begin{array}{c}\text { layanan } \\
\text { Sikap Empati } \\
\text { Siswa }\end{array}$ & $\begin{array}{c}\text { cenguasaan } \\
\text { konten }\end{array}$ \\
\hline $\mathrm{N}$ & & 154 & 154 \\
Normal Parameters & a,b & 131.16 & 79.13 \\
& Sean & 14.962 & 8.116 \\
Most Extreme Differences & Absolute & .104 & .107 \\
& Positive & .104 & .107 \\
Kolmogorov-Smirnov Z & Negative & -.100 & -.078 \\
Asymp. Sig. (2-tailed) & & 1.291 & 1.326 \\
\end{tabular}

a. Test distribution is Normal.

b. Calculated from data.

Pada tabel diatas terlihat bahwa nilai di kolom Sig. pada metode Kolmogorov-Smirnov untuk semua sampel terlihat Sig. Sikap Empati Siswa sebesar $0.071>0.05$ dan Sig. Layanan penguasaan konten dengan teknik modelling simbolik sebesar $0,06>0,05$, sehingga $\mathrm{H}_{0}$ diterima, dengan kata lain bahwa data dari semua sampel pada penelitian ini berdistribusi normal. Selanjutnya untuk membuktikan hipotesis penelitian, digunakan hasil perhitungan yang diperoleh melalui pengaplikasian program SPSS 20.0. Hasil perhitungan dan pembahasannya adalah sebagai berikut:

\section{Tabel 5. Hasil Pengujian Hipotesis Sikap Empati Siswa dan Layanan Penguasaan Konten}

Coefficients $^{\mathrm{a}}$

\begin{tabular}{|c|c|c|c|c|c|c|}
\hline \multirow[b]{2}{*}{ Model } & & \multicolumn{2}{|c|}{ Unstandardized Coefficients } & \multirow{2}{*}{$\begin{array}{c}\begin{array}{c}\text { Standardized } \\
\text { Coefficients }\end{array} \\
\text { Beta }\end{array}$} & \multirow[b]{2}{*}{$t$} & \multirow[b]{2}{*}{ Sig. } \\
\hline & & B & Std. Error & & & \\
\hline 1 & (Constant) & 48.632 & 9.808 & & 4.958 & .000 \\
\hline & $\begin{array}{l}\text { layanan penguasaan } \\
\text { konten dengan modelling } \\
\text { simbolik }\end{array}$ & 1.043 & .123 & .566 & 8.458 & .000 \\
\hline
\end{tabular}

a. Dependent Variable: Sikap Empati Siswa

Tabel diatas merupakan hasil pengujian hipotesis pada kelompok sampel siswa. Pengujian Hipotesis dianalisis dengan teknik korelasi dan regresi sederhana dengan bantuan SPSS 20,0 for windows. Adapun kriteria uji hipotesis yaitu: 


$$
\begin{aligned}
& H 0: \beta y 1=0 \\
& H 1: \beta y 1 \neq 0
\end{aligned}
$$

Artinya:

H0: tidak terdapat pengaruh layananpenguasaankontendenganteknik modelling simbolik terhadap sikapempatisiswa.

H1: terdapat pengaruh layanan penguasaan konten dengan teknik modelling simbolik terhadap sikap empat isiswa.

Dari Tabel 5.3 dapat dinyatakan bahwa terdapat pengaruh yang signifikan layanan penguasaan konten dengan teknik modelling simbolik terhadap sikap empati siswa. Hal ini dibuktikan dengan perolehan nilai Sig. 0,00<0,05 dan th $=8,458$. Adapun kontribusi variabel pengaruh layanan penguasaan konten dengan teknik modelling simbolik terhadap sikap empati siswa dapat dinyatakan dengan rumus:

$$
\begin{aligned}
& K D=\text { Nilai } \beta x 1 y \times \text { Nilai Korelasi Pasialnya }(r \times 1 y) \times 100 \% \\
& K D=1,043 \times 0,566 \times 100 \%=59,03 \%
\end{aligned}
$$

Dari hasil perhitungan di atas dapat dinyatakan bahwa kontribusi pengaruh layanan penguasaan konten dengan teknik modelling simbolik terhadap sikap empati siswa sebesar 59,03\%. Hasil pengujian hipotesis pada penelitian ini menunjukkan bahwa terdapat perbedaan rata-rata sikap empati siswa. Perbedaan rata-rata tersebut membuktikan adanya perubahan secara positif mengenai pemberian penguasaan konten yang diberikan terhadap sikap empati siswa. Berdasarkan uji regresi sederhana terlihat nilai Sig. $0.00<0.05$ sehingga jelas dinyatakan bahwa penguasaan konten memberikan kontribusi secara signifikan terhadap peningkatan sikap empati siswa.

\section{KESIMPULAN}

Berdasarkan kajian yang telah dilakukan selama penelitian maka dapat disimpulkan bahwa adanya kontribusi positif layanan penguasaan konten (PKO) dalam meningkatkan sikap empati siswa dan perubahan sikap empati siswa atas kontribusi layanan penguasaan konten (PKO) terjadi secara signifikan.

\section{DAFTAR PUSTAKA}

Auliyah, Alan dan Elia Flurentin. (2016). Efektifitas penggunaaan media film untuk meningkatkan empati siswa kelas VII SMP. Jurnal Kajian Bimbingan dan Konseling. $\quad 1 \quad(1) \quad$ : 19-26. Tersedia Online di http://journal.um.ac.id/index.php/bk. 
Azam, U. (2016). Bimbingan dan konseling perkembangan di sekolah teori dan praktik. Yogyakarta: Deepublish.

Desyafmi, H., Firman, F., \& Ifdil, I. (2016). Peningkatan motivasi siswa dalam menyelesaikan tugas melalui layanan informasi. Konselor, 3(1), 35-41.

Dewi, I. A. D. P., Antari, N. N. M., Erg, M., \& Dantes, N. (2014). Penerapan konseling kognitif sosial dengan teknik role playing untuk mengembangkan sikap empati pada siswa kelas xi ips 1 sma negeri 3 singaraja tahun ajaran 2013/2014. Jurnal Ilmiah Bimbingan Konseling Undiksha, 2(1) : 1-11.

Edy, Catur waskito. (2018). Tersedia di http:/ /jateng.tribunnews.com/2018/12/28/media-asing-bingung-rasaempati-para-tukang-pamer-dan-selfie-di-bencana-tsunami-anyer Diakses pada tanggal 1 Januari 2019.

Farida, N. I. (2014). Upaya meningkatkan kepercayaan diri siswa remaja putri yang mengalami pubertas awal melalui layanan penguasaan konten dengan teknik role playing di kelas vii smp n 13 semarang tahun ajaran 2013/2014 (Doctoral dissertation, Universitas Negeri Semarang).

Indriasari, Emi. (2016). Meningkatakan rasa empati siswa melalui layanan konseling kelompok dengan teknik sosiodrama pada siswa kelas xi ips 3 sma sunan kudus tahun ajaran 2015/2015. Jurnal Konseling GUSJIGANG. 2 (2) : 190-195. Tersedia https://jurnal.umk.ac.id/index.php/gusjigang/article/view/718.

Kamaluddin, H. (2011). Bimbingan dan konseling sekolah. Jurnal Pendidikan dan Kebudayaan, 17(4), 447-454.

Meidina, Putri. (2018). Pengembangan empati anak usia dini. Published Skripsi. Lampung : Universitas Lampung. http://digilib.unila.ac.id/32858/3/SKRIPSI\%20TANPA\%20BAB\%20PE MBAHASAN.pdf. Di Akses pada tanggal 13 Januari 2019.

School Of Parenting. (2018). Tersedia di https://schoolofparenting.id/empatiyang-hilang-dan-munculnya-generasi-tukang-bully/. Diakses pada tanggal 5 Januari 2019.

Tarigan, B. (2016). Meningkatkan rasa empati kepada sesama teman dalam mengurangi perilaku bullying melalui bimbingan kelompok teknik diskusi di kelas xi ips sma yapim air bersih medan tahun ajaran 2015/2016 (Doctoral dissertation, UNIMED).

Tohirin. (2014). Bimbingan dan konseling di sekolah dan madrasah (berbasis integrasi). Jakarta: Rajawali Press. 